\title{
Accession and Reform of the European Union
}

\author{
A Game-Theoretical Analysis of Eastern \\ Enlargement and the Constitutional \\ Reform
}

Thomas König

German University of Administratioe Sciences, Germany

Thomas Bräuninger

Unioersity of Konstanz, Germany

\begin{abstract}
This study examines how the institutional provisions of the Nice Treaty and the constitutional reform of the European Union (EU) will affect agricultural decision-making in the enlarged EU. Although the agricultural sector is a core EU policy domain, we have little knowledge about the effects of institutional reform following the accession of 10 relatively small and poor countries, each having a large primary sector. Based on an input-output taxation model, we identify the positions of old and new member states in the twodimensional space of EU agricultural politics. This allows us to investigate whether and how Council decision-making will change if the Nice Treaty's provisions for qualified majority voting are replaced by those of the draft constitution of 2004. Our analysis shows that the constitution is an advance providing for more policy change but it falls behind the Laeken proposal, which would have effectively reformed EU agricultural decision-making.
\end{abstract}

- agricultural policy

- core

- enlargement

- institutional reform

- qualified majority voting

- spatial model 


\section{Eastern enlargement, institutional reform and decision- making scenarios}

How does the recent accession of 10 East and South European countries change decision-making in the European Union (EU) - will the recent EU enlargement lead to gridlock and a redistribution of power and wealth? And to what extent can the constitutional reform of the EU reverse these effects does it offer more potential for policy change without shifting the balance between the 25 member states of the EU? Scholars have argued that the Nice Treaty, which defines the current EU decision-making provisions, has simply increased the veto power of member states (König and Bräuninger, 2000a; Felsenthal and Machover, 2001; Tsebelis and Yataganas, 2002). In order to avoid overruling new majorities, the Nice Treaty has modified the distribution of voting weights and introduced a complex triple majority criterion in the Council of Ministers that makes EU decision-making even more difficult (Wessels, 2001: 201). The reasoning for this is that the 2004 accession of 10 countries from Eastern and Southern Europe not only increased the number of member states to 25 but also brings the risk of redistribution because the new members are relatively poor with small populations and large agricultural sectors. These countries will benefit from the current system of direct payments, production quotas and other management instruments, which is largely financed by GNP-based contributions from only a few member states.

In this article, we simulate the effects of Eastern enlargement by comparing qualified majority decision-making in the agricultural policy area under the rules of the Nice Treaty, the Laeken draft and the constitutional reform proposal adopted by the heads of government on 18 June 2004 . We select qualified majority decision-making in agricultural politics for three reasons. First, agricultural politics remains one of the most important EU policy domains on which the EU spends more than half of its budget. Second, this policy domain reveals the danger of a redistribution of net benefits because old and new member states differ significantly with respect to the relative importance of their primary sector. Third, the Council of Ministers adopts most legislation by qualified majority, including legislative decisions concerning agricultural issues.

We begin our analysis by focusing on the changes in the Council of Ministers, which is the central voting body in EU decision-making: all legislative proposals must be adopted by at least a qualified majority of the member states in the Council. Changes in the Council, however, may also affect the inter-institutional power relationship between the member states, the Commission and the Court of Justice because the latter two possess more discretionary power in the event of a gridlocked Council (Tsebelis, 2002). 
Thus, we hope that our empirical analysis of agricultural decision-making also provides important insights into the effects of institutional reform and enlargement on the power balance between the Council, the Commission and the Court of Justice.

For the purpose of analysis, we use the game-theoretic concept of the qualified majority voting (QMV) core, which is the set of all policies or alternatives that cannot be changed by a qualified majority of member states. ${ }^{1} \mathrm{We}$ assume that all outcomes are located in the core: policies outside the core will move into the core because these outcomes will improve the welfare of a qualified majority of the member states. Policies inside the core cannot be changed. We accordingly presume that every member state is interested in being located in, or close to, the center of the core. Under these assumptions, we draw our conclusions from two observations: First, if the QMV core shrinks, we conclude that the EU under the draft constitution would face less legislative gridlock. That is, the size of the core determines the likelihood for political immobility. Second, if the center of the core moves away from the policy positions of individual countries, we conclude that the reform of decision-making provisions will change the balance between the member states at the cost of these countries. This means that the individual distance to the center of the core defines the danger of redistribution. ${ }^{2}$

Our study attempts to provide new insights into institutional reform and Eastern enlargement in two important ways. First, we present a twodimensional spatial analysis of agricultural policy outcomes based on the specific provisions for qualified majority voting and the 25 member countries' positions that we derive from an input-output tax payers model. Our model is motivated by empirical findings that reveal a strong relationship between decision-making in the Council and both agricultural and total net transfers per capita (Carrubba, 1997; Rodden, 2002; Mattila, 2002). Second, we assess the effect of institutional provisions, hereby controlling for the conflicting interests of 25 member states rather than making simplifying assumptions on the preference distribution. This will improve our understanding of the complex relationship between preferences, institutional reform and accession. Building on these results, our approach allows us to assess the effects of institutional reform, notably to compare those of the Nice Treaty and the constitutional reform proposal, and to specify which countries can expect to benefit from reform and accession.

Our findings reveal that the constitutional reform proposal addresses some of the problems associated with Eastern enlargement. Although the accession of these 10 countries will increase the propensity for gridlock and change the balance between member states under the provisions of the Nice Treaty, the constitutional reform will modestly shrink the QMV core of 
agricultural policy-making and move it towards the old members. The Laeken reform would have allowed for more legislative activities without increasing the danger of redistribution in the domain of agricultural policy-making. This result also has implications for the role of other EU institutions, such as the Commission and the European Court of Justice. The Nice Treaty and, to a smaller extent, the draft constitution empower these supranational institutions because member states can hardly limit their discretionary power.

\section{From Nice to a constitution: The reform of institutional reform}

The accession of Central and East European countries to the EU was a historic opportunity to end the postwar division of Europe. At the Helsinki summit in 1999, the 15 member states decided to open negotiations on the accession of 10 post-communist states that emerged from the break-up of the Soviet bloc. Two small South European countries, Cyprus and Malta, complete this accession group. The remarkable decision to almost double the number of EU members was linked early on to the reform of the institutional framework of the EU. Originally designed by six founding members in the late 1950s, this framework was periodically refined in the course of earlier accessions, most notably with the extension of qualified majority voting in the Council after the Southern enlargement in the mid-1980s (Garrett, 1992; Bednar et al., 1996). The fundamental reform problem is that decision-making in the Council is often gridlocked when member states differ significantly in their policy positions but are required to make decisions (quasi-)unanimously (Scharpf, 1988). Decreasing the voting threshold, however, entails the risk that some members may be overruled, especially countries with extreme policy positions (Tsebelis and Garrett, 1999).

Prior to the accession of the Central and East European countries, all member states agreed on the necessity of reforming the voting scheme in the Council, but they were unable to find an acceptable solution at the Amsterdam Intergovernmental Conference in 1997. A French proposal sought to reweight the votes in favor of the large countries, and Germany proposed the introduction of an additional population quota. The reasoning for both proposals lies in the fact that most accession candidates are relatively poor and have small populations and large agricultural sectors. Most old member state governments feared that the existing institutional framework would enable the group of accession countries to shift EU legislative outcomes considerably, particularly legislation relating to agricultural and structural program expenditures, which make up by far the largest part of the EU budget. 
Three years later, the intergovernmental conference at the Nice Summit adopted institutional reforms that finally entered into force in February 2003. Among these reforms, the 15 member states agreed to modify the voting scheme for qualified majority voting. The result is a complex procedure reflecting both the French and the German proposals from Amsterdam (Wessels, 2001; Felsenthal and Machover, 2001). In addition to a new distribution of the voting weights for old and new member states, ${ }^{3}$ the Nice Treaty increases the voting threshold from $71.2 \%$ to $73 \%{ }^{4}$ and adds a population quota requiring the inclusion of at least $62 \%$ of the EU population. As a compromise with smaller member states, the new scheme also requires a majority of member states to be in favor of the legislative proposal. Obviously, these rules increase the danger of gridlock, and in an annex to the Nice Treaty, entitled 'Declaration on the future of the Union', the need for another round of reforms had already been stressed (Wessels, 2001: 201).

The Laeken European Council held in December 2001 was intended to initiate the process of further debate on the future of the EU. A Convention was convoked to propose suggestions on how to change the institutional framework, notably with respect to the power distribution in the EU, the simplification of the treaties, the role of national parliaments in the enlarged EU, and the need to increase legitimacy and transparency. The President of the Laeken Council, Valéry Giscard d'Estaing, inaugurated the Convention on 28 February 2002. The Convention was composed of 207 members and 13 observers, of whom only 66 had the right to vote on the final document. Members with the right to vote included the President and the two VicePresidents of the Convention, 15 delegates of the member state governments (one from each country), 30 representatives of the national parliaments (two from each member state), 16 members of the European Parliament, and two officials from the Commission. The representatives of 13 accession countries (one government representative and two delegates of the national parliament from each country) were not entitled to vote but were invited to discuss and participate in the negotiations.

During the first, 'listening' phase, which continued until summer 2002, the members of the Convention presented their views about the future of the EU (Maurer, 2003: 28). From September to March 2003, the presidency pursued the second or so-called 'study' phase of the Convention. Specific issues were discussed and the presidency established a working group system for their preparation. In Spring 2003, the last and decisive phase of the Convention began, the so-called 'drafting' period. On 13 June 2003, after hectic and intense debates, the overwhelming majority of the Convention accepted the draft constitutional treaty. The text simplifies the complicated QMV procedure of the Nice Treaty, introducing a 'double' majority, according to 
which a simple majority of member states representing at least three-fifths of the EU population can adopt legislative initiatives. ${ }^{5}$ Large states favored the provisions of the June 2003 draft proposal, whereas small member states stood in strong opposition to it. Spain and Portugal, in particular, which had benefited greatly from the Nice Treaty, were afraid of having a reduced influence on EU decision-making (Cameron, 2004).

These recent developments show how difficult and decisive the issue of qualified majority voting in the Council is for the constitutional development of the EU. Since the Amsterdam Intergovernmental Conference in 1997, member states have struggled to find and adopt an effective solution for reforming EU decision-making in preparation of Eastern enlargement. The Nice Treaty (2003) opened the way for a widening of the Union, but it is feared that the provisions promote legislative gridlock by increasing the veto power of a number of member states. The Laeken Convention presented a new reform proposal that prompted new concerns for smaller member states. They were, however, able to postpone the adoption of a European constitution at the Brussels Intergovernmental Conference at the end of 2003, and the Irish presidency worked out a compromise that was accepted at the Brussels summit on 18 June 2004. Compared with the Laeken proposal, the modified constitutional proposal increases the threshold for QMV by at least 5\%: a qualified majority will be defined as including at least $55 \%$ of the members of the Council, comprising at least 15 of them and representing at least $65 \%$ of the population of the EU. Additionally, a blocking coalition must have at least four members. This raises the question of whether the constitutional proposal can effectively address the problem of gridlock and redistribution induced by Eastern enlargement. However, before presenting our reform analysis, we would like to provide a realistic view of the increasing dissimilarities between old and new members in the enlarged EU.

\section{Policy positions of old and new member states in agricultural policy-making}

Many studies analyze the institutional modifications of EU decision-making under the strong assumption of a uniform preference distribution of member states. Power analyses, for instance, widely assume that actors' policy positions are uniformly distributed (Lane and Berg, 1999; Holler and Widgrén, 1999; Steunenberg et al., 1999). Under this condition, cooperative voting power (Felsenthal and Machover, 2001) and non-cooperative legislative game analyses (Carrubba and Volden, 2001; Steunenberg, 2002) study the individual power distribution among countries and the EU's collective 
'capacity to act' (Coleman, 1971: 269). These are important conditions, because the assumption of a uniform preference distribution refers to membership size only. We believe that this focus on size risks disregarding a crucial feature of the present and some previous enlargements, namely the differences between current and future member states in their policy positions. ${ }^{6}$

Comparing the smooth Northern enlargement, through which the wealthy countries of Austria, Finland and Sweden became members in 1995, with the 1986 Southern enlargement, which led to the accession of Greece, Spain and Portugal, we see that this feature was also decisive for reform because the EU introduced QMV with the Single European Act in 1987. The two enlargement rounds differed not in size but with respect to the differences in the policy positions of Northern and Southern member states. The early discussions about institutional reform in the event of Eastern enlargement also revealed fears concerning the dissimilarity between current and future members of the EU. This (dis-)similarity is based on the fact that from today's perspective the accession of all applicants would increase the EU population by around $30 \%$ but its GDP by only $4 \%$ (Baldwin et al., 1997; Kandogan, 2000).

To study the interaction of institutional provisions and divergent interests in the EU, we concentrate on agricultural policy-making. This domain has become the most integrated one, is almost exclusively regulated at the EU level and has significant budgetary implications. Eastern enlargement will purportedly increase the importance of the agricultural dimension of the EU even further. The reason for this is that, first, many accession countries are heavily dependent on agriculture and have an unfavorable farming structure - a large number of small farms and the existence of durable semi-subsistence farming combined with the presence of an emerging commercial farming sector. This dualism of structures poses a range of administrative and economic dilemmas for the Common Agricultural Policy (CAP) (Commission of the European Communities, 2002: 3). Second, the agricultural sector in general and the poor, rural regions in particular currently receive a large part of total EU spending. Since most new members are relatively poor and still have an important primary sector, an unchanged CAP is likely to increase the total budget - even if one controls for the cohesion of accession countries (Baldwin et al., 1997). In spite of this effect, many studies assume that the input and output rules governing agricultural politics will not change significantly when the constitutional reform comes into force (Kandogan, 2000: 698).

Taking into account differences between the 25 old and new member states, we present a preference-based analysis of Eastern enlargement and institutional reform. To uncover the countries' benefits from EU reform and enlargement, we simulate the core location of the (enlarged) EU under both 
the current and the reform scenarios. Tsebelis and Garrett (2001) previously used the concept of the core when they argued that legislative outcomes account for the process of European integration. They stress, in addition to Moravcsik's (1998) intergovernmental approach, that understanding the consequences of intergovernmental choices to deepen or widen the EU first necessitates analyzing how these choices will affect the interactions among the EU's major institutions. In their view, such an analysis also allows us to speculate on the discretionary power of the Commission and the Court of Justice (Pollack, 1997; Alter, 1998; Meunier, 2000). In essence, supranational bureaucrats and judges are likely to have more discretionary power when new legislation is difficult to pass in the Council of Ministers because they can move policy outcomes closer to their interests. Theoretically, this is a function of the number and location of veto players in terms of the actors, or in terms of the outcomes or size of the core in the Council of Ministers (Tsebelis, 2002: 30). A large core increases the probability of gridlock in the Council, and a shift of the core increases the danger of redistribution.

We believe that Eastern enlargement will affect this function for two reasons. First, the accession of rather poor and small states increases the preference heterogeneity among member states. Thus, it is likely that the size of the core in the Council will expand. We expect to find such changes in the agricultural sector because new and old member states differ with respect to the importance of their primary sector. Second, the institutional reform intends to change the institutional balance between the decision-making bodies and proposes to change the voting scheme of the Council. Our analysis will consider the interaction between both components - institutional reform and the accessions of small and poor countries with large primary sectors.

Conducting such a simulation of EU agricultural policy-making requires identifying the policy positions of actors on the relevant issue dimensions. Data on future policy positions, however, do not (and cannot) exist for old and new member states. Although we may find some data on member states' current policy positions (for an overview, see Zimmer et al., 2004), we do not know how they will act in an enlarged EU. Economic indicators of the agricultural sector performance of member states may better illustrate the variation among countries, but they cannot be interpreted as the countries' policy positions. We will approach this problem by using a simple tax payer model (Romer and Rosenthal, 1978) to translate macroeconomic indicators into positions in a two-dimensional policy space that consists of the countries' input and output sides in agricultural policy (see the appendix).

The input side refers to the question of how much a country must pay for the provision of agricultural goods in the EU, while the output side considers the distributive effects of these outcomes. The model suggests a two-dimensional representation of single-peaked policy positions with high 
preference by wealthy member states for decreasing budgets (see Propositions 1 and 2 in the appendix). Since wealthy countries pay more than they profit from the collective goods of the EU, they generally prefer domestic solutions to a policy problem. Moreover, the less a country gains from a policy area, the smaller is its most preferred spending level for that domain (see Proposition 3 in the appendix).

To operationalize the two dimensions, we consider two indicators: first, the importance of the agricultural sector for the national economies (agriculture as a share of GDP) and, second, their wealth (GDP per capita). ${ }^{7}$ The former reflects output-side agricultural policy-making; the latter considers the input side of member states in the budget of the EU. As to the budget revenue, the most important of the four types of resource are those related to GNP. The idea behind GNP resources is that member states' contributions should be proportional to their capacity to pay as measured by economic wealth. Since the exact rate is determined during the budgetary procedure, this type of resource is considered to be an instrument used to bring budgetary revenue in balance with expenditure (Nugent, 1994: 343). Currently, GNP resources constitute about half of the total budgetary revenue. Given the fact that redistributive objectives are pursued through expenditure alone, we assume that the budget contributions of member states reflect the conflict over the size of the budget: wealthier countries (measured by GDP per capita) profit less from redistribution than poorer countries do and thus prefer a smaller EU budget. ${ }^{8}$

Regarding the output side, the importance of the agricultural sector should give a reasonable account of the expenditure space in agricultural politics. Over time, the importance of the primary sector for the national economies has decreased in both accession countries and old member states but, in terms of levels, the former are still much more dependent on agricultural sector production. In this respect, Greece is a notable outlier among the old member states; Germany, the United Kingdom and Luxembourg, in contrast, have the lowest primary sector share. Accordingly, we presume that the higher a member state's dependency on the agricultural sector (as a share of GDP), the more it favors EU budget expenditure on agriculture. ${ }^{9}$

\section{The analysis: Comparing the location and the size of the core}

Spatial models of legislative choice have been applied to the analysis of the interplay between actors' policy positions and the institutional framework of the EU (e.g. Tsebelis, 1994; Meunier, 2000; König and Pöter, 2001). In these models, actors are assumed to possess ideal points in a policy space. The more distant the policy alternatives are from the actor's ideal point, the less 
attractive they are. Assuming that actors have complete and perfect information, outcomes depend on the voting scheme and the location of the status quo. In this ideal type world, actors reach decisions instantaneously. To predict policy outcomes, we use the game-theoretical concept of the core. This concept stands for the set of all alternatives that cannot be defeated by a majority of the votes. The application of the core concept allows us to disregard speculation about the location of the status quo ${ }^{10}$ because the core is internally and externally stable: if the status quo is located outside the core, the outcome will be located inside the core - as at least one alternative within the core will be (sequentially) superior to the status quo for at least one winning coalition; if the status quo is located inside the core, policy change is impossible since at least one actor of any winning coalition would be worse off (Hinich and Munger, 1997: 61). Applied to the current procedures of the $\mathrm{EU}$, the qualified majority core (QMV core) covers the set of status quo policies that cannot be defeated by a majority of more than $73 \%$ of weighted votes, a minimum of $62 \%$ of the total population and a simple majority of member states. The Laeken and the draft constitution intend to abolish the first criterion of more than $73 \%$ of weighted votes. The two proposals differ in the voting thresholds involving the number of member states and the population.

In the following, we derive the QMV core for the 25 member states and compare its size and location with the QMV cores for three scenarios, with and without institutional reform. ${ }^{11}$ This indicates how outcomes are likely to shift under the constitutional reform proposal. Note that we consider all provisions of the old and new QMV voting scheme in the Council of Ministers, which is the dominant decision-making rule in the Council of Ministers and applies to the assent, standard, cooperation and co-decision procedure (Wessels, 2001: 205). In our comparative analysis of a shifting of the core center, we draw conclusions on member states' preferences for institutional reform, and we interpret changes in the size of the core as a function of the power of the supranational actors, the Commission and the Court of Justice.

Supranational powers of the judiciary and the bureaucracies are shaped by the size of the core because their decisions can be overruled more easily by a legislative body with a large potential for policy change. In this case, the Court of Justice and the Commission are likely to avoid decisions and interpretations with which the Council of Ministers - and to some extent the European Parliament - disagrees (Burley and Mattli, 1993; Pollack, 1997). However, as the core of legislative decision-making expands, the supranational actors can make the first move in terms of interpreting the existing laws, which can hardly be overruled by the legislature (Tsebelis and Yataganas, 2002). 


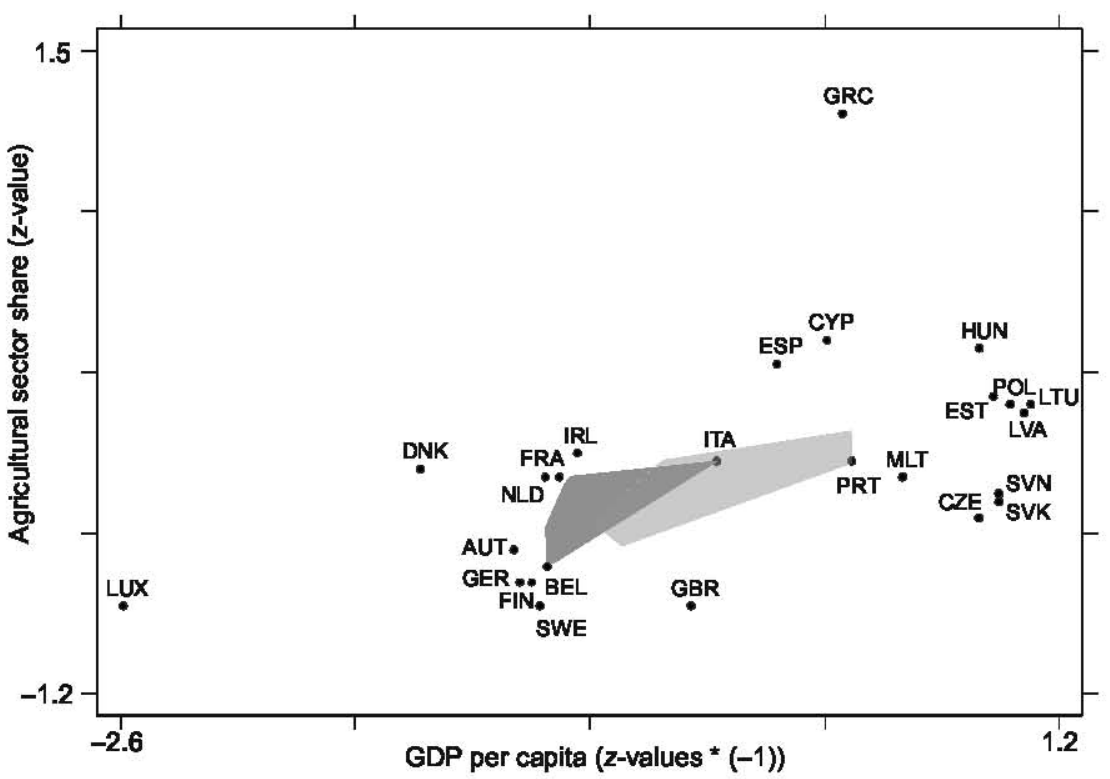

Key: $\square$ core of EU15 (Nice Treaty voting rules), $\square$ core of EU25 (Nice Treaty voting rules). AUT $=$ Austria, BEL = Belgium, CYP = Cyprus, CZE = Czech Republic, DNK = Denmark, ESP = Spain, EST = Estonia, FIN = Finland, FRA = France, GBR = United Kingdom, GER = Germany, GRC = Greece, HUN = Hungary, IRL = Ireland, ITA = Italy, LTU = Lithuania, LUX = Luxembourg, LVA = Latvia, MLT = Malta, NLD $=$ Netherlands, POL = Poland, PRT = Portugal, SVK = Slovakia, SVN = Slovenia, SWE $=$ Sweden .

Figure 1 Location and size of the core in agricultural politics in EU15 and EU25 after the Nice reform.

Our model relies on the standard assumption that member states consider their distance between their policy positions and the core outcomes in terms of utility loss. In general, any member state has high interest in being in, or as close as possible to, the core. If a member state is located within the core it knows that any policy change will lead to outcomes that are close to its ideal point. Moreover, a 'core member' can veto any QMV decision that aims at changing the status quo. We further assume that reform preferences result from comparing the distances to core outcomes that can be changed by reform. However, since the core may cover a set of outcomes, we simplify our analysis by using the center of the core as the reference point for comparison. Figure 1 shows our findings for agricultural politics under the Nice provisions with the accession of 10 member states.

Figure 1 illustrates the configuration of the policy positions of old 
member states and accession countries. Among the current member states, Luxembourg and Greece are the outliers: Luxembourg prefers a lowering of the European budget and of agricultural policy expenditure, whereas Greece favors the opposite - an increase in both. Other member states are relatively close together, even though a so-called 'spendthrift' group consisting of Portugal, Spain and Italy prefers an increase in both, whereas the 'fiscally conservative' group of Austria, Belgium, Germany, Finland and Sweden favors a lowering of the budget and of agricultural spending. A mixed group consists of Denmark, the Netherlands, France and Ireland. This agricultural pressure group favors agricultural spending but also opts for a lowering of the total budget of the EU.

The effect of Eastern enlargement on the QMV core is shown by the shaded areas. The dark-shaded QMV core of the 15 member states encompasses Italy and Belgium, and comes close to the French position. This means that the former two countries currently have a veto player position in agricultural policy-making while other member state policy positions can be outvoted under QMV. The accession of Cyprus, the Czech Republic, Estonia, Hungary, Latvia, Lithuania, Malta, Poland, Slovenia and Slovakia has changed this. All of these countries favor an increase of the total budget and in agricultural expenditures. Under the Nice provisions for QMV, the size of the core will expand significantly and therefore strengthen the discretionary power of the supranational actors. Moreover, the QMV core will move considerably away from the group of fiscally prosperous countries. Although the old and the new cores are partially overlapping, only Italy will preserve its veto player position and Portugal will become a veto player. These findings confirm the skeptical view that Eastern enlargement without institutional reform is problematic. Figure 2 shows whether and how the Laeken and the constitutional reform proposal could change the situation in the enlarged EU.

In Figure 2, the policy positions of the 25 member states remain unchanged. In order to show the reform effects of the Laeken draft and the constitutional proposal, we reconstruct the QMV core of the enlarged EU under the provisions of the Nice Treaty. Compared with the Nice QMV core, the result of the Laeken draft suggests that the QMV core would have shrunk, notably by abolishing the requirement of $73 \%$ of weighted votes. The very small dark area of the Laeken QMV core indicates that the reform proposal could have effectively reduced the gridlock danger of EU decision-making after the Eastern enlargement. Moreover, these provisions would have limited the power of the Commission and the Court of Justice because member states would have been able to overrule judiciary and bureaucratic decisions. Another question concerns the balance between the member states, which is answered by the location of the QMV core. According to our findings, the Laeken QMV core is located almost in the middle of the Nice QMV core. This 

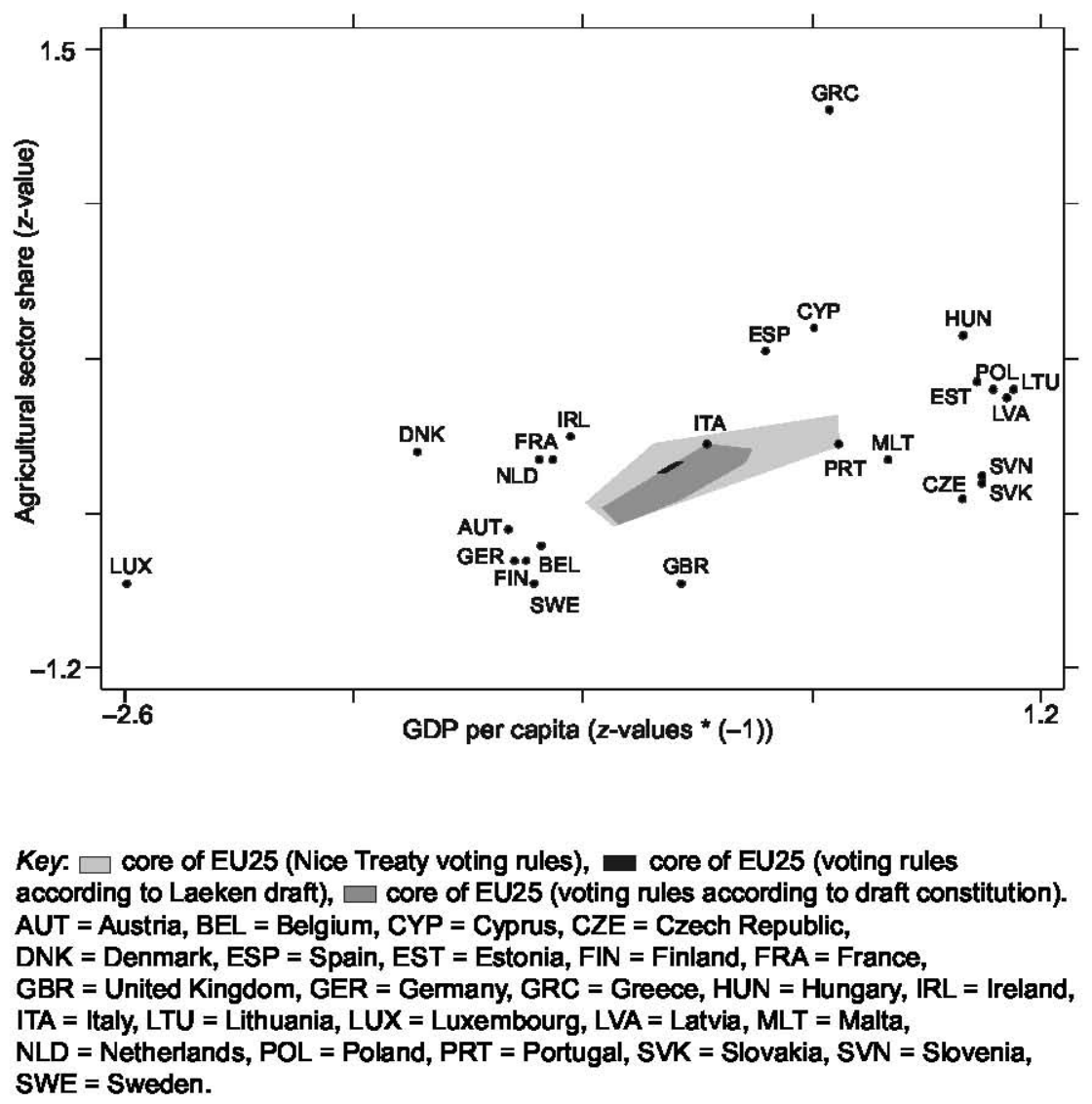

Figure 2 Location and size of the core in agricultural politics in EU25 after Laeken and draft constitutional reform.

suggests that every member state would have faced a higher danger of redistribution induced by the reduction of veto power. The compromise solution, adopted at the Brussels Summit on 18 June, also reduces the size of the Nice QMV core. However, compared with the Laeken draft, the constitutional proposal will re-establish the situation prior to Eastern enlargement. The size and location of this QMV core are almost identical to the Nice solution before the 10 members joined the EU in May 2004.

\section{Outlook}

The aim of this study was to provide a different and in some ways more accurate view of EU decision-making with respect to enlargement and 
institutional reform by taking into account the apparently dissimilar interests of old and new member states. Our spatial study of agricultural decisionmaking set out, first, to uncover the gridlock and redistribution danger under the institutional provisions of the Nice Treaty, and, secondly, to compare them with the effects of the Laeken draft and the constitutional reform proposal, which prompted skepticism among smaller member states. Although Eastern enlargement and EU integration affect a number of further policy areas, we still view agricultural politics as one of the most important areas because it accounts for more than half of the EU budget and illustrates the more extreme differences between new and old member states.

For the purpose of analysis, we identified the two-dimensional policy positions of the 25 member states by introducing a tax-payer model that allows us to locate both old and new member states using macroeconomic data. Admittedly, the macroeconomic position of a member state is only one, and by no means the only, determinant of its policy position. However, compared with other studies, which make more general and stronger assumptions about the preference distributions of the member states, we believe that our approach takes the important variation across member states better into account. Using this approach for the analysis of previous accession rounds, we were able to show why institutional reform has been linked to particular enlargements of the EU (König and Bräuninger, 2000a,b). We use the location and the size of the QMV core because qualified majority voting is considered to be the most common voting rule in the EU framework. Note that this approach can easily be applied to unanimous voting and to other reference points in the QMV core.

Our findings reveal that the Nice QMV core expands enormously as a result of the accession of 10 Eastern countries. Although the Nice Treaty modestly raises the formal veto power of the member states, the increased heterogeneity of member state positions will threaten the effective functioning of agricultural decision-making. This result is also relevant for the power of the Commission and the Court of Justice, because bureaucratic and judiciary discretionary power will increase in the event of a highly gridlocked legislature. Conversely, the Laeken QMV core would have shrunk notably and been located in the middle of the Nice QMV core. This means that the Laeken reform offered a high potential for policy change and it also promised to keep the balance between large and smaller, new and old, as well as rich and poorer countries. The constitutional proposal will re-establish the situation prior to Eastern enlargement in terms of the size and location of the core.

Our findings contradict previous research on institutional reform, in particular the conclusion of voting power studies suggesting that Germany 
would have gained (voting) power from the provisions of the Laeken draft and the constitutional proposal. We thus believe that voting power analysis, which uses the strong assumption of uniform preference distribution, cannot provide a realistic view of Eastern enlargement. Our alternative, and probably more accurate, view of Germany and Spain shows that the two opponents of the Brussels summit in December 2003 have similar distances to the new QMV core. This indicates that a fair solution for effectively reforming EU decisionmaking is possible, even in agricultural policy-making. The Laeken draft would have moved the EU towards a majority system in which the legislature is the dominant player of EU integration. The constitutional reform proposal can also solve the problems induced by Eastern enlargement, but it will change the power distribution neither among member states nor between the Council, the Commission and the European Court of Justice.

\section{Appendix}

Each country $i$ is assumed to optimize its consumption of a bundle of private goods $\left(C_{i}\right)$ and of collective goods provided by the EU $\left(G_{i}\right)$. Private goods are produced at the domestic level. They can and do benefit only a single country, whereas EU goods are collectively financed and politically allocated. They may be pure public or private goods or of some intermediate type (Kraan, 1996: 35). In general, EU collective goods result from a number of policies that are financed by EU budget expenditures, where the total budget is the sum of all policy expenditures $\left(E=E_{1}+\ldots+E_{m}\right)$. Countries try to maximize their (strictly quasi-concave) utility function $U_{i}\left(C_{i}, G_{i}\right)$.

Policies often have distributive effects, and some countries may gain more than others. The gain of each country thus depends on a function $f_{i}$, with $G_{i}=f_{i}(E)$. If $f_{i}$ is increasing and weakly concave, then a new function $u_{i}\left(C_{i}, E\right)=U_{i}\left(C_{i}=f_{i}(E)\right)$ is also strictly quasi-concave and non-decreasing in $\left(C_{i}, E\right)$. In addition to these distributive effects, the countries may contribute differently to the budget of the EU. Let $T=\left(T_{1}, \ldots, T_{n}\right)$ be the tax system of the EU, where $T_{i}(E)$ is the contribution that a country $i$ has to spend for the budget level $E$. The maximization problem of a member state can then be described by:

$$
\begin{gathered}
\max u_{i}\left(C_{i}, E\right) \\
\text { s. t. } C_{i}+T_{i}(E) \leq B_{i} .
\end{gathered}
$$

where $B_{i}$ is the domestic budget.

Figure 3 shows the indifference curves of a country $i$ regarding the size of the EU budget $(E)$ and its private consumption $\left(C_{i}\right)$. The size of the domestic 


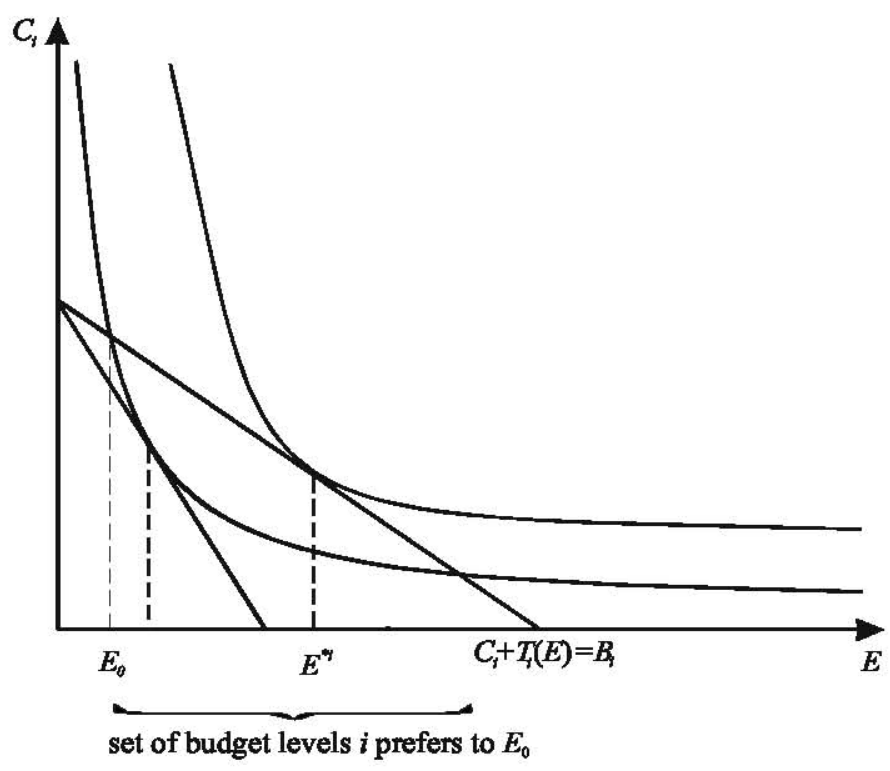

Figure 3 Optimal choices for individual states.

budget is related to the altitude of the budget line, the individual tax structure and its slope. At the EU budget $E_{0}$, the country is in a suboptimal position because the indifference curve intersects its domestic budget constraint at that point. Its optimal output is at the European budget level $\left(E^{* i}\right)$, where a (higher) indifference curve touches its domestic budget constraint.

This results in a constrained utility function having two characteristics:

Proposition 1: For any country there is a most preferred collective spending level $E^{*}$, which is the ideal point of a single-peaked preference in the policy space of EU budget revenues.

Proof: cp. Romer and Rosenthal (1978: 30).

Proposition 2: The larger a country's individual contribution to the EU budget, the smaller is its most preferred total budget.

Proof: As the budget line will be steeper whenever $T_{i}$ is increasing, the point representing the ideal budget level moves to the left, i.e. $\partial E^{* i} / \partial T_{i}<0$.

Since wealthy countries pay more than they profit from collective goods provided by the EU, they should generally prefer domestic political solutions. However, the EU produces collective goods in different policy areas. In this case, the support of wealthy countries on the provision of EU collective goods depends on the importance they attach to these policy areas. This leads to the 
question of whether the optimal spending level of a country on a policy is decreasing when either it is less interested in the policy or it is expecting lower gains. For the sake of simplicity, consider a Cobb-Douglas utility function to describe the countries' unconstrained preferences on a single collective good $\left(E_{j}\right)$ and a composite good $\left(D_{-j}\right)$ as being the consumption alternative:

$$
w_{i}\left(E_{j}, D_{-j}\right)=E_{j}^{\alpha_{i}} D_{-j}^{1-\alpha_{i}} \quad \alpha_{i} \in(0,1)
$$

The Cobb-Douglas functional form includes convex preferences, where $\alpha_{i}$ is a parameter of the gains that the country receives from a policy as compared with anything else; $\alpha_{i}$ can thus be interpreted as the country's salience on the policy. In general, $\alpha_{i}$ will depend on both the specific (economic or political) characteristics of the country and the (distributive) consequences of the policy. Using elementary differential calculus and considering that, at the optimal spending level, the slope of the budget line $(t)$ equals $\mathrm{d} D_{-j} / \mathrm{d} E_{j}$, we obtain the ratio between expenditures for the policy and all other goods by:

$$
E_{j}^{* i}=\left(1-\frac{1}{1-\alpha_{i}}\right) \frac{1}{t} D_{-j}
$$

This leads to the third proposition:

Proposition 3: The less a country gains from a policy, the smaller is its most preferred spending level for that policy.

Proof: As the slope of the budget line $t$ is negative, the composite good $D_{-j}$ is positive and $\alpha_{i}$ varies between 0 and 1 , we have: $E_{j}^{* i}$ is decreasing whenever $\alpha_{i}$ is decreasing, i.e. $\partial E_{j}^{* i} / \partial \alpha_{i}>0$.

\section{Notes}

We are grateful to Cliff Carrubba for sharing his data on EU fiscal transfers.

1 The rules for QMV were intensively debated at the Nice (2000) and Brussels (2004) summits and became one of the cornerstones of institutional reform. The Laeken Convention also made suggestions for reforming QMV, which were adopted in a modified version at the Brussels summit in June 2004.

2 Without further knowledge on the location of the status quo, it is reasonable to expect that the center of the core is the average outcome, given a uniform distribution of all outcomes in the core. Other assumptions would correspond to extreme views of enlargement and institutional reform: a pessimistic view would be represented by the largest distance, an optimistic view by the smallest distance between a country and the core border.

3 The new weights are: Germany (29), United Kingdom (29), France (29), Italy (29), Spain (27), the Netherlands (13), Greece (12), Belgium (12), Portugal (12), Sweden (10), Austria (10), Denmark (7), Finland (7), Ireland (7), Luxembourg (4). The weights for accession countries are: Poland (27), Romania (14), Czech Republic (12), Hungary (12), Bulgaria (10), Slovakia (7), Lithuania (7), Latvia (4), Slovenia (4), Estonia (4), Cyprus (4), Malta (3). 
4 The Declaration on the qualified majority threshold and the number of votes for a blocking minority in an enlarged Union continues: 'Insofar as all the candidate countries listed in the Declaration on the enlargement of the European Union have not yet acceded to the Union when the new vote weightings take effect (1 January 2005), the threshold for a qualified majority will move, according to the pace of accessions, from a percentage below the current one to a maximum of 73.4 per cent. When all the candidate countries mentioned above have acceded, the blocking minority, in a Union of 27, will be raised to 91 votes, and the qualified majority threshold resulting from the table given in the Declaration on enlargement of the European Union will be automatically adjusted accordingly.'

5 In cases where the Council is not acting on a proposal by the Commission or the High Representative for the Common Foreign and Security Policy (CFSP), a qualified majority consists of two-thirds of the member states, representing at least three-fifths of the population.

6 For the purpose of analysis, other studies assume that member states are divided into larger groups, such as Northern and Southern member states (Hosli, 1996) or large and smaller countries (Schmitter, 2000; Tsebelis and Yataganas, 2002), and that the accession of many small Eastern countries raises concerns among the large countries. However, except for the accession of the United Kingdom in 1973, all previous accession candidates were relatively small and/ or regionally biased, but member states never made enlargement contingent on institutional reform (König and Bräuninger, 2000a).

7 We use GDP - instead of GNP-standardized values for reasons of comparability. All figures are based on their three-year average (1999-2001) and $z$ standardized (EU Directorate-General for Agriculture, 2000, 2001, 2002; World Bank, 2003).

8 According to Proposition 2 (see the appendix), the larger a country's individual payment to the EU budget, the smaller is its most preferred total budget. To confirm that our measure properly captures the pattern of budget contributions, we regress member states' annual per capita contributions to the EU budget (CON/CP) on their GDP per capita (GDP/CP). Data are taken from Carrubba (1997) and cover the period 1977-94. In contrast to Carrubba's (1997: 481) analysis of budget revenue, we use cross-section data averaged over the period to assess the long-term redistributive effects rather than stabilization effects of the EU budget (see de la Fuente and Doménech, 2001). The estimated equation is $(N=12, F(1,10)=22.71$, standard errors in parentheses, ${ }^{*}$ denotes significance at $1 \%$ level $)$ :

$$
\mathrm{CON} / \mathrm{CP}=-.004(.019)+9.880\left(2.073^{* *}\right) \mathrm{GDP} / \mathrm{CP},
$$

where CON/CP and GDP/CP are measured in 1000 constant 1985 ECUs. Thus, less prosperous member states make smaller contributions to the budget and we assume them to be more in favor of total budget increases than are countries with a higher GDP per capita.

9 Proposition 3 (see the appendix) states that the less a country gains from agricultural policy, the smaller is its most preferred spending level for Common Agricultural Policies. To assess the validity of our indicator for benefits from agricultural policies, we regress average annual EU expenditure per capita (consisting of $56-81 \%$ agricultural spending in the time period) on the size 
of agriculture as a share of GDP. The estimated equation is $(N=12, F(1,10)$ $=6.79$, standard errors in parentheses, ${ }^{*}$ denotes significance at $5 \%$ level $)$ :

$$
\mathrm{EXP} / \mathrm{CP}=.040(.018)+.011\left(.004^{*}\right) \mathrm{AGR} / \mathrm{GDP},
$$

where EXP/CP is measured in 1000 constant 1985 ECUs. We therefore conclude that countries with a higher agricultural sector will be in favor of more agricultural expenditure.

10 Tsebelis (2002) argues that, in political science analysis, it is not easy to locate the status quo because it remains unclear what the status quo was until after a proposal was decided. Moreover, studies that depend on the location of the status quo have an extremely contingent character because the status quo may vary over time, particularly in cases where the location is determined by exogenous events (e.g crises).

11 QMV cores are calculated using the program LIMED (Bräuninger, 2003). LIMED (available at <http://www.tbraeuninger.de/download/download. $\mathrm{html}>$ ) requires the commercial program GAUSS and computes limiting q-dividers (hyperplanes) for two- and three-dimensional spatial models.

\section{References}

Alter, Karen (1998) Who Are the Masters of the Treaty? European Governments and the European Court of Justice', International Organization 52(1): 121-47.

Baldwin, Richard, Joseph Francois and Richard Portes (1997) 'The Costs and Benefits of Eastern Enlargement: The Impact on the EU and Central Europe', Economic Policy 12(24): 125-76.

Bednar, Jenna, John Ferejohn and Geoffrey Garrett (1996) 'The Politics of European Federalism', International Review of Law and Economics 16(3): 279-94.

Bräuninger, Thomas (2003) 'When Simple Voting Doesn't Work: Multicameral Systems for the Representation and Aggregation of Interests in International Organizations', British Journal of Political Science 33(4): 681-703.

Burley, Anne-Marie and Walter Mattli (1993) 'Europe before the Court: A Political Theory of Legal Integration', International Organization 47(1): 41-76.

Cameron, David R. (2004) 'The Stalemate in the Constitutional IGC over the Definition of a Qualified Majority', European Union Politics 5(3): 375-93.

Carrubba, Clifford J. (1997) 'Net Financial Transfers in the European Union: Who Gets What and Why?', Joumal of Politics 59(2): 469-96.

Carrubba, Clifford J. and Craig Volden (2001) 'Explaining Institutional Change in the European Union: What Determines the Voting Rule in the Council of Ministers', European Union Politics 2(1): 5-30.

Coleman, James S. (1971) 'Control of Collectivities and the Power of a Collectivity to Act', in Bernhardt Lieberman (ed.) Social Choice, pp. 269-99. New York: Gordon \& Breach.

Commission of the European Communities (2002) 'Enlargement and Agriculture: Successfully Integrating the New Member States into CAP', Issues Paper, URL (consulted June 2004): <http://europa.eu.int/comm/enlargement/docs/ financialpackage/sec2002-95_en.pdf > .

De la Fuente, Angel and Rafael Doménech (2001) 'The Redistributive Effect of the 
EU Budget: An Analysis and Proposal for Reform', Joumal of Common Market Studies 39(2): 307-30.

EU Directorate-General for Agriculture (2000, 2001, 2002) Agriculture in the European Union: Statistical and economic information, URL (consulted April 2004): $<$ http://europa.eu.int/comm/agriculture/agrista/archive_en.htm>.

Felsenthal, Dan S. and Moshé Machover (2001) 'The Treaty of Nice and Qualified Majority Voting', Social Choice and Welfare 18(3): 431-64.

Garrett, Geoffrey (1992) 'International Cooperation and Institutional Choice: The European Community's Internal Market', International Organization 46(2): 533-60.

Hinich, Melvin and Michael Munger (1997) Analytical Politics. Cambridge: Cambridge University Press.

Holler, Manfred and Mika Widgrén (1999) 'Why Power Indices for Assessing European Union Decision-Making?', Journal of Theoretical Politics 11(3): 321-30.

Hosli, Madeleine (1996) 'Coalitions and Power: Effects of Qualified Majority Voting in the Council of the European Union', Joumal of Common Market Studies 34(2): 255-73.

Kandogan, Yener (2000) 'Political Economy of Eastern Enlargement of the European Union: Budgetary Costs and Reforms in Voting Rules', European Journal of Political Economy 16(4): 685-705.

König, Thomas and Thomas Bräuninger (2000a) 'Governing the Enlarged European Union: Accession Scenarios and Institutional Reform', Central European Political Science Review 1(1): 42-62.

König, Thomas and Thomas Bräuninger (2000b) 'The Union's Institutional Reforming and Enlargement', in The NEBI Yearbook - North European and Baltic Sea Integration, pp. 227-42. Heidelberg: Springer.

König, Thomas and Mirja Pöter (2001) 'Examining the EU Legislative Process: The Relative Importance of Agenda and Veto Power', European Union Politics 2(3): 329-51.

Kraan, Dirk-Jan (1996) Budgetary Decisions: A Public Choice Approach. Cambridge: Cambridge University Press.

Lane, Jan-Erik and Sven Berg (1999) 'Relevance of Voting Power', Journal of Theoretical Politics 11(3): 309-20.

Mattila, Mikko (2002) 'Fiscal Redistribution in the European Union and the Enlargement', mimeo, University of Helsinki.

Maurer, Andreas (2003) Schließt sich der Kreis? Der Konvent, nationale Vorbehalte und die Regierungskonferenz. Teil I. SWP Working Paper. Berlin: Stiftung Wissenschaft und Politik.

Meunier, Sophie (2000) 'What Single Voice? European Institutions and EU-U.S. Trade Negotiations', International Organization 54(1): 103-35.

Moravcsik, Andrew (1998) The Choice for Europe. Ithaca, NY: Cornell University Press.

Nugent, Neill (1994) The Government and Politics of the European Union, 3rd edn. London: Macmillan.

Pollack, Mark (1997) 'Delegation, Agency, and Agenda Setting in the European Community', International Organization 51(1): 99-134.

Rodden, Jonathan (2002) 'Strength in Numbers? Representation and Redistribution in the European Union', European Union Politics 3(2): 151-75.

Romer, Thomas and Howard Rosenthal (1978) 'Political Resource Allocation, Controlled Agendas, and the Status Quo', Public Choice 33(4): 27-43. 
Scharpf, Fritz W. (1988) 'The Joint-Decision Trap - Lessons From German Federalism and European Integration', Public Administration 66(3): 239-78.

Schmitter, Philippe (2000) How to Democratize the European Union ... and Why Bother? Lanham, MD: Rowman \& Littlefield.

Steunenberg, Bernard (2002) 'Enlargement and Reform in the European Union', in Bernard Steunenberg (ed.) Widening the European Union: The Politics of Institutional Change and Reform, pp. 3-20, London: Routledge.

Steunenberg, Bernard, Dieter Schmidtchen and Christian Koboldt (1999) 'Strategic Power in the European Union: Evaluating the Distribution of Power in Policy Games', Journal of Theoretical Politics 11(3): 339-66.

Tsebelis, George (1994) 'The Power of the European Parliament as a Conditional Agenda Setter', American Political Science Review 88(1): 128-42.

Tsebelis, George (2002) Veto Players: How Political Institutions Work. Princeton, NJ: Princeton University Press.

Tsebelis, George and Geoffrey Garrett (1999) 'Why Resist the Temptation to Apply Power Indices to the European Union', Journal of Theoretical Politics 11(3): 291-308.

Tsebelis, George and Geoffrey Garrett (2001) 'The Institutional Foundations of Intergovernmentalism and Supranationalism in the European Union', International Organization 55(2): 357-90.

Tsebelis, George and X. Yataganas (2002) 'Veto Players and Decisionmaking in the EU after Nice: Legislative Gridlock and Bureaucratic/Judicial Discretion', Journal of Common Market Studies 40(2): 283-307.

Wessels, Wolfgang (2001) 'Nice Results: The Millennium IGC and the EU's Evolution', Journal of Common Market Studies 39(2): 197-219.

World Bank (2003) World Development Indicators. Washington, DC: World Bank.

Zimmer, Christina, Gerald Schneider and Michael Dobbins (2004) 'The Contested Council: The Conflict Dimensions of an Intergovernmental Institution', mimeo, University of Konstanz.

\section{About the authors}

Thomas König is Professor of Political Science at the German University of Administrative Sciences Speyer, Freiherr-vom-Stein-Str. 2, 67346 Speyer, Germany.

Fax: +496232654127

E-mail: tkoenig@dhv-speyer.de

Thomas Bräuninger is Head of an Emmy Noether Junior research group, Department of Politics and Management \& Center for Junior Research Fellows, University of Konstanz, Universitätsstr. 10, 78457

Konstanz, Germany.

Fax: +497531884103

E-mail: thomas.braeuninger@uni-konstanz.de 